\title{
The Relationship Between Outsourcing And Organizational Performance
}

\begin{abstract}
Dr Asiamah Yeboah, Faculty of Business and Management Studies, Kumasi Polytechnic

The purpose of this study is to examine the relationship between outsourcing and organizational performance in the services sector. The population of the study is made up of 50 firms operating in the banking and insurance sectors of the economy of Ghana. The paper used purposive sampling for the selection of the respondents. Questionnaires were distributed to the respondents for statistical analysis. The study utilized Statistical Package for the Social Sciences (SPSS) to analyze the data collected. The study revealed a number of findings including: there is no statistically significant correlation between outsourcing and organizational productivity, there is statistically significant correlation between outsourcing and quality, there is statistically significant correlation between outsourcing and competitive advantage. Based on the findings, some recommendations were made most importantly: there must be thorough background check before outsourcing, and organizations must also have a back-up system to avoid losing vital data as a result of incompetence on the part of the external supplier.
\end{abstract}

Keywords: outsourcing, organizational performance, competitive advantage, resources, productivity, quality, off shoring

\subsection{INTRODUCTION}

Most firms are in business for the purpose of making profit. These firms then put measures in place to reduce costs in order to increase profits. A common strategy that is commonly used for this purpose which has brought some debate in both academia and professional practice is outsourcing; a common trait of business-to-business firms. Outsourcing is the process whereby firms purchase products and services from other companies than to make the products or perform the services internally (Bearden, Ingram, Lafarge, 2007). Some companies believe that this is more cost effective; as it allows them to concentrate on their core competencies and to purchase the products or services from expert companies than to produce in-house. For example, TV3 Ghana Limited outsources its internet services from UCOM Ghana Limited. The television giant does this to cut down on the costs it would incur in creating an internet service and managing it themselves as well as remaining competitive. Some other firms also outsource because they need to improve their quality and speed of software maintenance and development. Others also believe that outsourcing is now offering much value than it previously did.

Initially, the concept of outsourcing was more popular among the companies found in the manufacturing sector. Companies such as Boeing, BMW, General Motors and Siemens, who are in the manufacturing industry, source from smaller companies in Bulgaria. However, it has now permeated into other sectors of the economy including services and the government. In the services, telephone answering systems, customer services, technical support, among others are also being outsourced. The business functions that are commonly outsourced are information technology (IT) and human resources.

Any organization that wants to outsource from other companies could do so from another company in the same country or it may choose to follow the example of America Online, who outsource their human resources for handling their call center calls in India. This is also a practice that is gaining much ground in the art of outsourcing. (David L. Kurtz, et al. Principles of Marketing, [2006] $12^{\text {th }}$ edition)

Companies always make the impact of outsourcing on their financial performance a major priority when taking the decision to outsource. To many firms, the risk of functions may be cut or reduced through outsourcing activities, thereby making it possible to save cost through zero defects in manufacturing components through expert companies. Outsourcing is also used in managing time when non-productive areas that take up the time and efforts of workers are sourced from external suppliers. These are mostly non-value adding areas including support services such as facility management, and contract catering services. Problems are better managed where external specialists are trusted with these functions. Management therefore gets enough time to focus on its core competence.

Reducing and controlling operation costs is a major factor forcing firms into outsourcing as sourcing from external suppliers is proven to be more cost effective than in-house production. The overheads cost on a product or service and 
European Journal of Business and Management

sometimes promotional cost may be passed on to the external provider reducing the cost to be incurred when produced in-house. Outsourcing may minimize staff cost for people working on non-routine initiatives such as research and training. The capital requirements such as securing and equipping a new internet server may be reduced through outsourcing. Short term capital can be generated through selling off facilities that are no longer significant as those activities are outsourced. Through this, cash can be generated for other areas of priority thereby enhancing the financial performance of the firm.

On the other hand, outsourcing may pose a threat when quality is a key concern for the outsourced work as intellectual capital and knowledge could be lost. There is also the issue of damaged morale and motivation in the organization through outsourcing as in-house expertise may be diminished. Confidence and lack of customer knowledge may also be a deciding factor for most firms when considering outsourcing. The performance of external providers may also impact on the firm's financial performance. However, a firm needs to consider several factors that may influence its financial performance through outsourcing in deciding whether or not to outsource. The work is organized into sections for which this introduction is followed by the problem statement. The next section also deals with the research objectives which is divided into main and sub-objectives. The other sections are research methodology, data analysis, findings, conclusion and recommendations.

\subsection{PROBLEM STATEMENT}

Some companies consider it more profitable to produce their products and services in-house whiles others see it more profitable to source from other expert companies. As noted earlier, outsourcing is a strategy that has become very crucial in most firms' corporate decisions. As far as corporate strategy is concerned, the final decision may always have a positive or negative impact on the organization's financial position in the long run.

Some firms, after considering some financial benefits with regards to outsourcing, likely decide to go for it. On the other hand, some hold back due to certain misgivings about the entire outsourcing strategy. They are of the view that the organization's ability to quickly respond to the marketplace will be deeply affected when outsourced.

While others say outsourcing is the best way to enhance the financial performance of an organization, others say in-house production is the best option. This has created some academic degree of uncertainty and the need to conduct a study into the relationship between outsourcing and organizational performance.

\subsection{OBJECTIVES OF THE RESEARCH}

The general objective of this study is to find out the relationship between outsourcing and organizational performance of firms in Ghana. The specific objectives are; to

- Determine the relationship between outsourcing and organizational profitability.

- Find out whether outsourcing leads to increased productivity or not.

- Determine the relationship between outsourcing and product/service quality.

- Ascertain whether outsourcing leads to competitive advantage or not.

\subsection{LITERATURE REWIEW}

\subsection{INTRODUCTION}

This literature intends to explore the themes in the research topic; Outsourcing, and impact on organization financial performance. The elements of concepts in this chapter do not intend to be complete. In order to enable easy comprehension of this discussion, this chapter seeks to explain the key elements of the research topic.

The underlining motive for outsourcing is cost reduction. Companies contract external suppliers that can produce products and services at a lower cost than the company can produce in-house. Companies' ability to get a good outsourcing deal will have a positive impact on profitability and vice versa, which is a major determinant of a company's financial performance.

\subsection{RISE OF OUTSOURCING AND OFFSHORING}

Chances are that if you dial a call center for a firm like America Online, your call will be answered by someone in India. Accenture and IBM have information technology present there as well. For those U.S based firms that want to remain close to but take advantage of the benefits of locating some of their operations overseas, Mexico and Canada are attractive locations. In today's competitive market place, firms look outside the U.S to improve efficiency and cut costs on just about everything from mailroom management, customer service, human resources, and accounting to information technology, manufacturing, and distribution. Outsourcing, using outside vendors to produce goods and services formally produced in-house or in-country is a trend that continues to rise. Businesses outsource for several reasons: 
European Journal of Business and Management

(1) They need to reduce cost to remain competitive,

(2) They need to improve the quality and speed of software maintenance and development,

(3) Outsourcing has begun to offer greater value than ever before.(David L. et al. 2006, p. 200).

Outsourcing allows firms to concentrate their resources on their core business. It also allows access to specialize talent or expertise that does not exist within the firm. The most frequently outsourced business functions include information technology (IT) and human resource. Many hospitals and manage-care organizations spent more than a third of their IT budget on outsourced consulting and supportive services. Although the majority of outsourcing is done by North American-based companies, the practice is rapidly becoming common place in Asia, Europe and Central America. In the U.S, a firm called Paychecks' is one of the largest national providers of payroll, human resource, and benefits outsourcing solutions for other companies, with nearly a half-million clients. Most of Paychecks' customers are small to medium-size firm, but the company also has a division called major market services, which handle large cooperation's.(David L. et al. 2006, p. 200).

Software is now a billion-a-year industry in the U.S. But many firms are now outsourcing their business to other countries, in particular India. Some experts believe IT outsourcing to Indian will grow as much as 30percent in one year. One reason is that cost of labour - a starting call center operator or a programmer with a college degree will earn around \$10,000a year. Another reason is the large pool of highly educated, English-speaking workers. In addition, there is currently a short form of tech students in the U.S. "The US is number three (3) in the world and falling quickly behind number one (1) India and number two (2) China in terms of computer-science graduates".(Microsoft CEO Stephen A.Ballmer).

Although the language barrier in China is still an obstacle for U.S. and European companies considering outsourcing, experts note that Eastern Europe is becoming an increasingly popular outsourcing location. Giants such as Boeing, BMW, General motors, Siemens, and Nortel contract small programming firms in Bulgaria, while IBM, Hewlett-Packard, Oracle, and Alcatel have support centre or software labs in Romania. German powerhouse SAPAG has a Bulgarian research lab with 180 engineers who write Java Software for SAPAG's innovative products around the world. Despite the current trend, several analysts say the U.S. programmers can be as successful as their overseas counterparts if they master the people skills required to build relationships with business customers. Firms are looking for people who can manage teams that may be scattered around the world. Outsourcing can be a smart strategy if companies choose a vendor that can be provide high-quality products and perhaps at a lower cost than could be achieved on the company's own. This priority allows the outsourcer to focus on its core competencies. Successful outsourcing requires companies to carefully oversee contracts and manage relationships. Some vendors now produce performance guarantees to assure their customers that they will receive high-quality services that meet their needs.(David L. et al. 2006, p.201).In recent years, a political firestorm has been ignited by a different form of outsourcing: the movement of high-wage jobs from the U.S. to lower-cost overseas locations, a business practice referred to as Off shoring. This relocation process to a lower-cost location can involve production off shoring and service off shoring. China has immerged as the preferred destination for production off shoring, while India has emerged as the dominant player in the service off shoring.

Business leaders argue that global business must continue to work to achieve the lowest possible cost in order to remain competitive. (David L. et al. 2006, p.201).

As noted earlier, an important trend in recent times has been the growing use of outsiders to carry out an organization's business. This employment of outsiders is called outsourcing. Organizations contract external providers for all form of business activities such as:

- Business functions (e.g. advertising, human resource, marketing research, etc.)

- Operational processes (e.g. customer service, procurement or recruitment, telemarketing etc.) thus Business Process Outsourcing (BPO)

- Business infrastructure (e.g. telecommunications networks, business information system, security system, etc.)

The underlying rationale for outsourcing is clearly economic. Companies have determined that they can do business more cheaply by working with outsiders than by relying on their internal workforce.(Lacity and Willcocks, 1995). This happens in various ways.

Offshore Outsourcing is a situation where contracts are awarded to a provider in another country. Off shoring focuses on services provided abroad and it is an extension of manufacturing overseas. To many companies, offshore production allows companies to take advantage of the low cost of overseas labour. This has been an area of interest to 
European Journal of Business and Management

firms with the growth of services in Asian countries such as India, Malaysia, China and Eastern Europe. Good telecommunications, computer technology and high educational standards coupled with low labour costs are creating large number of capable suppliers in the international market.

Outsourcing began with the manufacturing sector and continued into the service sector as a result of the underlying importance to marketing products and services. Now outsourcing has become dominant in service sector with much emphasis on the ability to reduce cost, add value and the corresponding impact on the company's financial performance.

\subsection{MARKETING FUNCTIONS THAT CAN BE OUTSOURCED}

External suppliers to marketing

\section{TABLE 1}

\subsection{MARKETING AND OUTSOURCING}

Managing marketing performance prioritizes the optimum use of resources (financial and human) to current market requirements. Planning for today focuses on shaping up the business to meet the needs of today's customers with excellence. Planning for today requires an organization that mirrors current business opportunities. Abell (1999).

Organizations now strive to be lean and fast-moving. Handy (1989) predicted shamrock organizations, with small numbers of full-time employees in core roles, and increasing proportions of activities being contracted out, as a means of dealing with a changing environment. Now organizations are outsourcing central functions to their business success, as well as routine activities where there is advantage in doing so (Linder, 2004). For example, pharmaceutical companies outsource R\&D to Contract Research Organizations (CROs). This market was worth $\$ 9.3$ billion in 2001(Reuters Business Insight, 2002).

Nick Wreden, a US management consultant, whose works has appeared in the Harvard Business School Press, specializes in how supply chain issues affect brands. He believes marketing will be the 'next wave of outsourcing.'His supporting reasons include that marketing is 'rarely a core competency', and that marketers have been buying in their expertise in functional areas for years. He believes that the quality of internationally based external suppliers is now so high that it is inevitable that they will attract a greater share of marketing work, citing the quality of different suppliers, such as Philippines' TeamAsia, which works with Microsoft; and Jack Yan \& Associates in New Zealand who continue to innovate.

Initially, marketers survived the threat of outsourcing because they added intellectual expertise. Now, they need to add more 'intellectual capital'. It is critical that they understand the role of distribution, data integration, forecasting and branding, and have strong customer communications. Marketers now need to use knowledge for competitive advantage. The core marketing knowledge exists throughout the developing nations, but currently few understand management of marketing performance.

Wreden advocates that marketers use overseas resources for efficiency where appropriate, passing the savings to clients. It is clear that most compelling reasons for international outsourcing are that outsourcing providers charge less than the fees of US agencies, without reducing value. So, this tells marketers that they must deliver value.

TABLE 2

Organizations are becoming more value and cost oriented and the need to optimize resources for the desired result. Non-core marketing functions such as advertising, database management, etc., are therefore contracted out to specialist external suppliers to undertake. This is more cost effective than undertaking such activities in-house.

\subsubsection{Generic View of the Merits and Demerits of Outsourcing}

There is no single model for deciding whether or not to employ the service of external suppliers in existence. This decision is normally made based on the analysis of business process and assessment of the reasons for seeking external suppliers. However, evaluation always includes subjective assessment.

The cost benefit is also often unclear here. Marketers are often unaware of the costs of undertaking work internally or because of budgeting methods and uncertainty over evaluating the activities, especially creative processes. (Traditional measures of success for some suppliers do not measure the commercial outcomes required, for the award winning agencies are not always those which have the best result against campaign objectives.) However, these need a revision, especially in light of the organization's responsibility to its shareholders or the key stakeholders.

\subsubsection{Initial Evaluation Overview}


European Journal of Business and Management

An initial evaluation overview will thus looks at factors to guide the decision on what to outsource and whether to outsource. Some key factors are summarized below.

There are other areas of evaluation and the relative importance of these areas varies depending on the organization, industry and the task to be undertaken.

\subsubsection{Legal Requirement}

Another major factor that influences outsourcing decision is legal or regulatory requirement. This influence can be seen through:

Contract conditions: These conditions imposed by insurers or conditions related to security or privacy may restrict the use of external suppliers.

Statute: Some public organizations, for example, are restricted by law from contractors (for security reasons). The restricted areas are reducing and governments are increasingly operating Compulsory Competitive Tendering (CCT) policies, thus requiring public sector providers to face competition from the commercial sector.

Regulatory Body: Professional bodies require work to be undertaken by people with approved level of qualification and supervision.

\subsection{DETAILED EVALUATION}

Assuming the outcome to the first stage in the process identifies the potential for using external suppliers, this process can move to the second stage which involves;

An audit of internal resources, cost, skills and competencies.

An external provision review, to identify suppliers and cost.

A clear identification of the activity or process to be undertaken by staff or external providers to focus the investigation is required. These processes need to be broken down into resource categories, such as expertise, equipment, people and money. These internal and external evaluations can be done simultaneously, or in an iterative process. They are not sequential.

\subsubsection{Internal Appraisal}

The Internal Resource Audit may be present in some form in the organization; otherwise, management must detail the staff by level, workload, skills and competencies in the area under the review. Another component here is costs and hours worked (including the overall cover). In addition, the review must measure the flexibility of staff to move to a different role if required. Any misfit between existing and required skills and abilities are identified and the cost of any overcoming these in an in-house provision calculated. The effects of using external suppliers such as the costs of redundancy payments, retaining or other support must be identified.

An Equipment Audit should also be undertaken. Equipment may be a requirement of the outsourced task, and indeed sometimes equipment is transferred as part of an outsourcing agreement. For instance if the outsourcing need relates to a database management activity, existing equipment can be compared to the equipment required to get the full work done.

Lastly, management must estimate the available budgets and determine the desirable expenditure, as a basis for discussion with the review of external suppliers.

\subsubsection{External Appraisal}

Requirement for undertaking the task, detailing the required characteristics, experience, resource and cost of external suppliers, forms the basis for the external review. The process does not emphasize on the choice of providers at this stage.

This appraisal involves information on the number and size of competitive suppliers, their reliability, range of service, past projects (including case history), example of work achievements and performance outcomes, their quality processes and staffing levels. Payment structures also form part of the review.

\subsection{THE DECISION TO OUTSOURCE}

The above assessment will reinforce the decision to outsource, what not to outsource or even which outsource organization to use. Evaluation includes measures to ensure that the decision is consistent at all levels. 
- Strategic: Strategies must answer; what is the impact on the organization's competitive position? What is the impact on the organization's brand position? Is the core competence under threat by this? Are our weakness reduced by this? Does this helps or hinder the long term development of asserts or expertise?

- Operational: What supervision and guidance is necessary for control and consistency with organizational requirements? What actions are required from the organization and the external supplier? What are the performance targets? How will these be measure? What are time-cost trade-off points?

- Organizational: How is the implementation linked to marketing strategy? How will it ensure result? Will this create conflict or loss of morale within the organization? Will this improve the organization's cost structure and profitability? Will this improve overall operational effectiveness?

This process should generate sufficient information to make a business case for an external supplier with evidence of economic value for external suppliers, with full consideration of the organization's policies, strategies and resources. It also creates an operational framework for briefing potential suppliers, showing how the two parties can work together to maximize value.

It's no longer a company's ownership of capabilities that matters but rather its ability to control and make the most of critical capabilities. Gottfredson et al. (2005).

Analysis of the value chain underpins many outsourcing decision. Porter viewed that the organization should focus on areas where it adds value, as Nike has done with branding and innovation, with external providers doing other activities. Doing what is a right (in quality, resource allocation and budget management) matters, but keeping this in-house often does not. As a result, outsourcing is growing in many business areas.

Gottfredson et al (2005) help us to understand that, the decision to outsource is one that takes firms on a winding road of making an initial assessment or evaluation and later a detailed one. The initial assessment considers extensively what the organization can choose to outsource based on its policies, the business need of the firm for outsourcing, as well as the experience of the external suppliers since such restraints seriously decide what the firm would consider a decision in its outsourcing. In the end, it would be done to make sure the organization would primarily benefit.

Other variables such as capability, cost, credibility, etc., also count when a firm is deciding on outsourcing from external agencies. This is of serious concern to a firm because, when the quality of whatever thatwould be produced in-house does not match those of competitors, then the need becomes even greater.

Legal issues also have a significant effect on the decision to outsource since regulatory bodies make it their concerns that work should be done that those with the necessary skills. Contract conditions can also make it difficult for firm with outsourcing since some may specifically require that sourcing from external parties or otherwise is not allowed. The initial evaluation now allows for the detailed evaluation for the outsourcing decision to be made. This then calls for an internal and an external appraisal as well as an analysis of the result. The analysis of the result through the use of Gottfredson et al's Outsourcing Opportunity Matrix (2005),would help the firm to know whether to outsource considering variables such as the cost per transaction and the firm's ability to perform the function.

When the firm has done all these analysis and has found that it is satisfied with the conclusions that it has come to, the decision to outsource is finally made.

\subsection{WHY OUTSOURCING}

\section{TABLE 3}

\subsection{PROBLEMS OR CHALLENGES WITH OUTSOURCING}

Outsourcing and Off shoring are not without problems. Many companies discover that their cost savings are less than the vendors sometimes promise. Also, companies that sign multiyear contracts may find that their savings drop after a year of two. When propriety technology is an issue, outsourcing raises security concerns. Similarly, companies that are protective of their customer data and relationships may think twice about entrusting functions like customer service to outside sources (Kurtz et al, 2006).

Outsourcing may not always deliver. Managers are poorly prepared for outsourcing. Bain's research shows that 82 percent of large companies in developed markets use outsourcing, but approximately half of these think that outsourcing does not meet their expectations. The cost savings only satisfy 10 percent of these respondents. However, outsourcing causes problems as well as having the potentials to solve those (Gottfredson et al).

In some cases, outsourcing and off shoring can reduce a company's ability to respond quickly to the marketplace, or it can slow efforts in bringing new products to the market. Suppliers who fail to bring goods promptly or provide quality 
European Journal of Business and Management

services can adversely affect a company's reputation with its customers. General Electronic had to delay the introduction of a new washing machine because of a contractor's production problems.

Another danger of outsourcing is the risk of losing touch with customers. When telecom giant Sprint realized that the customer data to its outsourced technology providers was not being put to work fast enough, the company decided to pull the plug on the external supplier. In their place, Customer Relationship Management (CRM) software was able to pull data on more than 10 million business accounts, saving Sprint $\$ 1$ million in the first year.

Outsourcing and Off shoring are controversial topics with unions, especially in the Auto industry, as the percentage of component parts made in-house has steadily dropped. These practices can create conflicts between non-union outside workers and in-house employees, who fear job loss. Management initiatives to outsource jobs can lead to strikes and plant shutdowns. Even if it does not lead to destruction in the workplace, outsourcing and off shoring can have a negative impact on employee morale and loyalty

\subsection{RESEARCH METHODOLOGY}

The study used a quantitative approach to determine whether or not outsourcing (the independent variable) can impact on organizational performance (the dependent variable) of service industry in Ghana. The study population includes 50 services companies operating in the Banking and Insurance sectors of the economy. The population is divided into two groups; the first group has to do with organizations operating in the banking sector numbering 30 , and the second group is the organizations doing business in the insurance sector numbering 20. Questionnaire and interviews were used to collect all the necessary data from the management and employees of the organizations mentioned earlier. With regards to the questionnaire, both open-ended and close-ended questions were used. This question style was adopted because it will facilitate ease understanding on the part of the respondents. It will also enable me to have a direct visual impression of the trend of events. The questionnaires were given to customers personally and they were assisted to fill. To get this respondents (sample- 50), purposive sampling techniques was used. That is, the selection of the respondents was as a matter of necessity. This technique was used because it helps in saving cost and the cost saving may be used to improve the quality of the research through increasing sample size. Again, the data, when compared to random methods which are perhaps double the cost, has been proved to be acceptable provided that the research is managed effectively. Statistical tools or normal distribution curves and software packages such as SPSS was used to analyze the data.

\subsection{DATA ANALYSIS}

\section{CORRELATIONS ANALYSIS}

\section{TABLE 4}

\section{The relationship between outsourcing and organization productivity}

\section{TABLE 5}

The coefficient of the above correlation analysis which is -0.24 shows that there is weak negative correlation between outsourcing and organizational productivity. This means that changes in outsourcing will not correlated with changes in the organizational performance. Therefore one can conclude that outsourcing and organizational productivity are not strongly correlated.

With regards to Sig (2-Tailed) value which is 0.867 , we can conclude that there is no statistically significant correlation between outsourcing and organizational productivity. That means, increases or decreases in outsourcing do not significantly relate to increases or decreases in organizational performance.

\section{Relationship between outsourcing and quality}

\section{TABLE 6}


European Journal of Business and Management

ISSN 2222-1905 (Paper) ISSN 2222-2839 (Online)

Vol.5, No.2, 2013

The coefficient of the above correlation analysis which is 0.218 shows that there is weak positive correlation between outsourcing and quality product or service. This means that changes in outsourcing will correlate with changes in the quality. Therefore we could conclude that outsourcing and quality are strongly correlated. In addition, Sig (2-Tailed) 7 value which is 0.129 , we can conclude that there is statistically significant correlation between outsourcing and quality. That's, increases or decreases in outsourcing do significantly relate to increases or decreases in quality.

\section{Relationship between outsourcing and competitive advantage TABLE 7}

The coefficient of the above correlation analysis $r=-0.165$ shows that there is weak negative correlation between outsourcing and competitive advantage. This means that as one variable increases (outsourcing) in value, the second variable decreases (competitive advantage) in value. We could conclude that when the organization continues to outsource from other organizations or if there is an increase in outsourcing, competitive advantage of the organization will decrease in value. In addition, Sig (2-Tailed) value which is 0.251 , we can conclude that there is statistically significant correlation between outsourcing and competitive advantage. That is, increases or decreases in outsourcing do significantly relate to increases or decreases in competitive advantage.

\subsection{FINDINGS}

The objective of this paper is to examine the relationship between outsourcing and organizational performance. This was done in order to ascertain whether carrying about business functions in-house or through external agencies is more profitable. The general assertion is that a well implemented outsourcing strategy would;

Reduce and control operating costs

Improve the firm's focus

Help the firm gain access to world-class capabilities

Helps in sharing risks, among others,

This will therefore have a positive impact on the financial performance of the firm. It is therefore obvious from the results that there is weak negative correlation between outsourcing and competitive advantage. This means that as one variable increases (outsourcing) in value, the second variable decreases (competitive advantage) in value. The results again show that there is weak positive correlation between outsourcing and quality product or service. This means that changes in outsourcing will correlate with changes in the quality.

\subsection{CONCLUSION AND RECOMMENDATIONS}

Based on the findings from the study, one can conclude that even though outsourcing enables organizations to focus on their core business yet, when the organization continues to outsource from other organizations or if there is an increase in outsourcing, competitive advantage of the organization will decrease in value. With this, the following recommendations could be made:

The firm must make sure that it recruits the services of third party firms that are trustworthy and credible. From the research carried out, most of the workers were assured that information being leaked to other competitors would be quite impossible if the external party comes highly recommended. It is therefore of greater importance that measures are put in place to check that information is protected.

A thorough and an extensive assessment of the firm must also be carried out to see if the firm carries out its functions outside. The commitment of the company would come into play here. It has been observed that outsourcing may not always be the strategic option for a firm in every situation, so, usually the best option would be to carry out the function in-house if they are well equipped to.

In order to avoid losing very vital data due to the incompetence of the external party, the firm must also make back up of all the information that it gives out. This would help the firm to evade losing very pertinent customer information.

\section{REFERENCES}

Abell, D., F., (1999), 'Competing Today while Preparing for Tomorrow', Sloan Management Review, 45(2), Spring, pages 73-78.

Barney, J., B., Hesterly, W., (1996), Handbook of Organizational Studies, Sage Publications, London. 
European Journal of Business and Management

Bearden, Ingram, LaForge, (2007), Marketing: Principles \& Perspectives, $5^{\text {th }}$ Edition, McGraw-Hill/Irwin, Seattle. Boone, E., L., Kurtz, D., L., (2002), Contemporary Marketing, South Western Thomson Learning, Ohio.

Contactbabel (2004), Finding the Balance: The Effect of Offshore Customer Contact on Profit and Brand.

Gottfriedson et al., (2005), 'Strategy Sourcing: From Periphery to Core', Harvard Business Review, 83(2), 132-139.

Khan, K., A., Pillania, R., A., (2008), 'Strategic Sourcing for Supply Chain Agility and Firms' Performance: A study of Indian Manufacturing Sector', Management Decision, Vol 46, Issue 10, pages 1508-1530.

Kurtz, D., L., et al, (2006), Principles of Marketing, $12^{\text {th }}$ Edition, South Western, Thomson Mason, Ohio.

Lacerda, D., P., Rodrigues, L., H., Cassel, R., A., Neto, S., C., (2012), 'Implications of Theory of Constraints (TOC) on Theory of Transactions-Cost-Economics Sourcing-Based Decision, International Journal of Business and Management Tomorrow, Vol 2 No 1, pages 73-86.

Lacity, M., Willcocks, L., Feeney, D., (1995), 'Information Technology Outsourcing: Maximizing Flexibility \& Control, Harvard Business Review, May-June, Vol. 73(3), pages 84-93.

Lacity, M., Willcocks, F., Feeney, D., (1996), 'Sourcing IT Capability: A Framework for Decision Making', Oxford University Press, pages 399-425.

Levina, N., Ross, J., (2003), From the Vendor's Perspective: Exploring the Value. Proposition in IT Outsourcing, MIS Quarterly, 27:3.

Linder, D., C., (2004), 'Transformational Outsourcing', MIT Sloan Management Review, 45(2), Winter, pages 52-58. Prahalad, C., K., Hamel, G., (1990), 'The Core Competence of the Corporation, Harvard Business Review', 68(3), pages 79-87.

Williamson, O., E., (1985), The Economic Institutions of Capitalism: Firms, Markets, Relational Contracting; Collier Macmillan Publishers, London.

\begin{tabular}{ll}
\hline Marketing-related agencies & Non-marketing related agencies \\
\hline Advertising & Banks \\
Contact management & Business Process \\
Conference and event organizers & Conference Organizers \\
Customer service & Health and Safety Specialists \\
Database management & Lawyers \\
Copywriting & IT System Management \\
Media buying & Publishers \\
Market and competitive research intelligence & Purchasing Specialists \\
Public relation & Hotel Reservation Services \\
\hline
\end{tabular}

Table 1. Extemal suppliers to marketing 
European Journal of Business and Management

\begin{tabular}{|c|c|c|}
\hline Issue & Organization undertake in-house when: & Organizations outsource when: \\
\hline Capacity & $\begin{array}{l}\text { Internal capacity is non-existent, limited } \\
\text { or flexible. }\end{array}$ & $\begin{array}{l}\text { they need rapid access to additional capacity } \\
\text { or resource. }\end{array}$ \\
\hline Capability & $\begin{array}{l}\text { Quality is a key concern for the outsourced } \\
\text { work. }\end{array}$ & $\begin{array}{l}\text { They wish to improve business } \\
\text { performance. }\end{array}$ \\
\hline Cost & $\begin{array}{l}\text { Cost will be higher than doing the work } \\
\text { in-house. }\end{array}$ & $\begin{array}{l}\text { Cost will be lower than doing the } \\
\text { work in-house. }\end{array}$ \\
\hline Customer & Customer reaction to outsourcing is negative. & Customer value outsourcing. \\
\hline Control & $\begin{array}{l}\text { There is concern over loss of control over } \\
\text { the process. }\end{array}$ & The external party guarantees the service \\
\hline Credibility & $\begin{array}{l}\text { Company credibility will be damaged throug } \\
\text { poor performance from the outsourcer }\end{array}$ & $\begin{array}{l}\text { They gain credibility by using a reputable } \\
\text { supplier. }\end{array}$ \\
\hline Compatibility & $\begin{array}{l}\text { Outsourced organization has goals that } \\
\text { are inconsistent with those of suppliers. }\end{array}$ & $\begin{array}{l}\text { Outsourced organization has goals that fit } \\
\text { and add to those of suppliers. }\end{array}$ \\
\hline Competitive & They think competitors will take over their & Outsourcer can add value to \\
\hline Issues & business. & Commissioning organizations or competitors \\
\hline
\end{tabular}

Table 2. Criteria for Initial Outsourcing Evaluation

Source: Wreden, $N$ (2004) Outsourcing.

\section{Reasons for Outsourcing.}

1. Reduces and control operating costs

2. Free internal resources for other purposes

3. Improves company's focus

4. Resources are not available internally

5. Accelerates reengineering benefits

6. Gain access to world-class capabilities

7. Difficult to manage or control function

8. Make capital funds available

9. Share risks

10. Cash infusion

Table 3. Top ten reasons for outsouring.

(Survey of Current and Potential Outsourcing End-User, The Outsourcing Institute members, 1998) 
European Journal of Business and Management

ISSN 2222-1905 (Paper) ISSN 2222-2839 (Online)

Vol.5, No.2, 2013

\begin{tabular}{|c|c|c|c|c|c|c|c|}
\hline & & outsourcing & $\begin{array}{l}\text { profitabilit } \\
y\end{array}$ & Quality & $\begin{array}{l}\text { orgarizationa } \\
\text { l performarce }\end{array}$ & $\begin{array}{l}\text { orgarizationa } \\
\text { l productivity }\end{array}$ & $\begin{array}{l}\text { competitive } \\
\text { advartage }\end{array}$ \\
\hline Outsourcing & $\begin{array}{l}\text { Fearson } \\
\text { Comelation } \\
\text { Sig. (2-tailed) } \\
\text { H }\end{array}$ & 50 & $\begin{array}{l}-.153 \\
.292 \\
49\end{array}$ & $\begin{array}{l}.218 \\
.129 \\
50\end{array}$ & $\begin{array}{l}-.233 \\
.103 \\
50\end{array}$ & $\begin{array}{l}-.024 \\
.867 \\
50\end{array}$ & $\begin{array}{l}-.165 \\
.251 \\
50\end{array}$ \\
\hline Frofitability & $\begin{array}{l}\text { Fearson } \\
\text { Conrelation } \\
\text { Sig. (2-tailed) } \\
\text { W }\end{array}$ & $\begin{array}{l}-.153 \\
.292 \\
49\end{array}$ & 49 & $\begin{array}{l}.058 \\
.694 \\
49\end{array}$ & $\begin{array}{l}\left.-.2877^{*}\right) \\
.045 \\
49\end{array}$ & $\begin{array}{l}-.099 \\
.500 \\
49\end{array}$ & $\begin{array}{l}.102 \\
484 \\
49\end{array}$ \\
\hline Quality & $\begin{array}{l}\text { Fearson } \\
\text { Correlation } \\
\text { Sig. (2-tailed) } \\
\text { H }\end{array}$ & $\begin{array}{l}.218 \\
.129 \\
50\end{array}$ & $\begin{array}{l}.058 \\
.694 \\
49\end{array}$ & 50 & $\begin{array}{l}-.397(* *) \\
.004 \\
50\end{array}$ & $\begin{array}{l}-.213 \\
.138 \\
50\end{array}$ & $\begin{array}{l}-.214 \\
.136 \\
50\end{array}$ \\
\hline $\begin{array}{l}\text { organizational } \\
\text { performance }\end{array}$ & $\begin{array}{l}\text { Fearson } \\
\text { Correlation }\end{array}$ & -.233 & $\left.-.2877^{*}\right)$ & $-.397(* *)$ & 1 & $.435(* *)$ & .096 \\
\hline 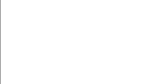 & $\begin{array}{l}\text { Sig. (2-tailed) } \\
\text { N }\end{array}$ & & $\begin{array}{l}.045 \\
49\end{array}$ & $\begin{array}{l}.004 \\
50\end{array}$ & 50 & $\begin{array}{l}.002 \\
50\end{array}$ & $\begin{array}{l}506 \\
50\end{array}$ \\
\hline $\begin{array}{l}\text { orgarizational } \\
\text { productivity }\end{array}$ & $\begin{array}{l}\text { Fearson } \\
\text { Correlation }\end{array}$ & -.024 & -.099 & -.213 & $.435(* *)$ & 1 & .117 \\
\hline & $\begin{array}{l}\text { Sig. (2-tailed) } \\
\text { N }\end{array}$ & $\begin{array}{l}867 \\
50\end{array}$ & $\begin{array}{l}500 \\
49\end{array}$ & $\begin{array}{l}.138 \\
50\end{array}$ & $\begin{array}{l}.002 \\
50\end{array}$ & 50 & $\begin{array}{l}.419 \\
50\end{array}$ \\
\hline $\begin{array}{l}\text { competitive } \\
\text { advartage }\end{array}$ & $\begin{array}{l}\text { Pearson } \\
\text { Correlation }\end{array}$ & -.165 & .102 & -.214 & .096 & .117 & 1 \\
\hline & $\begin{array}{l}\text { Sig. (2-tailed) } \\
\text { N }\end{array}$ & $\begin{array}{l}.251 \\
50\end{array}$ & $\begin{array}{l}484 \\
49\end{array}$ & $\begin{array}{l}.136 \\
50\end{array}$ & $\begin{array}{l}506 \\
50\end{array}$ & $\begin{array}{l}.419 \\
50\end{array}$ & 50 \\
\hline
\end{tabular}

TABLE 4 The relationship between outsourcing and organizationproductivity

\begin{tabular}{|ll|l|l|}
\hline & & outsourcing & organizational productivity \\
\hline outsourcing & Pearson Correlation & 1 & -.024 \\
& Sig. (2-tailed) & & .867 \\
& N & 50 & 50 \\
organizational & Pearson Correlation & -.024 & 1 \\
productivity & Sig. (2-tailed) & .867 & \\
& N & 50 & 50 \\
& &
\end{tabular}

TABLE 5 Relationshị between outsourcing and quality

\begin{tabular}{|c|c|c|c|}
\hline & & Outsourcing & Quality \\
\hline Outsourci & Pearson & & 218 \\
\hline ng & Correlation & 1 & .218 \\
\hline & Sig (2-tailed) & & .129 \\
\hline & $\mathrm{N}$ & 50 & 50 \\
\hline Quality & Pearson & 218 & 1 \\
\hline & Correlation & 210 & 1 \\
\hline & Sig. (2-tailed) & .129 & \\
\hline & N & 50 & 50 \\
\hline
\end{tabular}

TABLE 6 Relationship between outsourcing and competitive advantage 
TABLE 6 Relationship between outsourcing and competitive advantage

\begin{tabular}{|ll|l|l|}
\hline & & Outsourcing & competitive advantage \\
\hline outsourcing & Pearson & 1 & -.165 \\
& Correlation & & \\
& Sig. (2-tailed) & & .251 \\
& $\mathrm{~N}$ & 50 & 50 \\
competitive & Pearson & -.165 & 1 \\
advantage & Correlation & .251 & \\
& Sig. (2-tailed) & 50 & 50 \\
\hline
\end{tabular}


This academic article was published by The International Institute for Science, Technology and Education (IISTE). The IISTE is a pioneer in the Open Access Publishing service based in the U.S. and Europe. The aim of the institute is Accelerating Global Knowledge Sharing.

More information about the publisher can be found in the IISTE's homepage: http://www.iiste.org

\section{CALL FOR PAPERS}

The IISTE is currently hosting more than 30 peer-reviewed academic journals and collaborating with academic institutions around the world. There's no deadline for submission. Prospective authors of IISTE journals can find the submission instruction on the following page: http://www.iiste.org/Journals/

The IISTE editorial team promises to the review and publish all the qualified submissions in a fast manner. All the journals articles are available online to the readers all over the world without financial, legal, or technical barriers other than those inseparable from gaining access to the internet itself. Printed version of the journals is also available upon request of readers and authors.

\section{IISTE Knowledge Sharing Partners}

EBSCO, Index Copernicus, Ulrich's Periodicals Directory, JournalTOCS, PKP Open Archives Harvester, Bielefeld Academic Search Engine, Elektronische Zeitschriftenbibliothek EZB, Open J-Gate, OCLC WorldCat, Universe Digtial Library, NewJour, Google Scholar

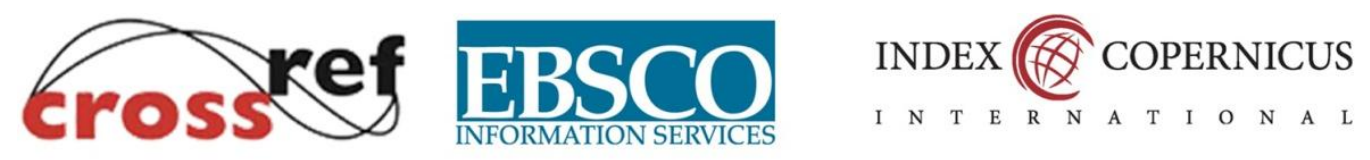

(O) ULRICHSWEB"

JournalTOCs

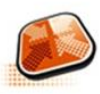

PKP | PUBLIC KNOWLEDGE PROJECT
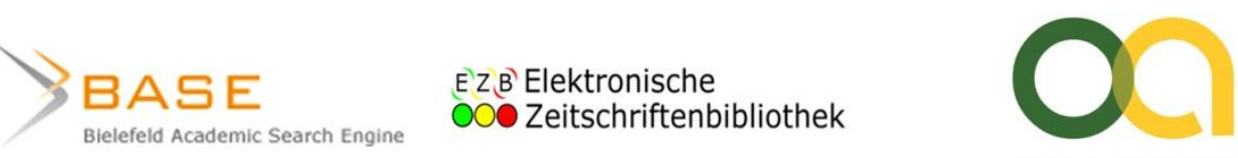

open access
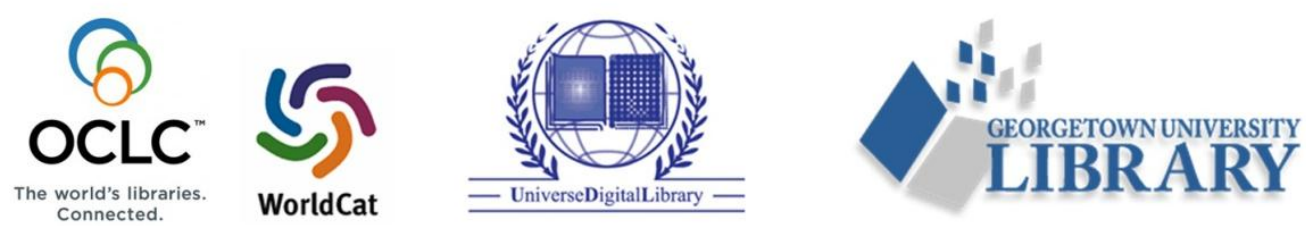